\title{
Undoing segmentation? Latin American health care policy during the economic boom
}

Juliana Martínez Franzoni and Diego Sánchez Ancochea

Paper accepted in Social Policy \& Administration, June 2018

\begin{abstract}
For all the agreement regarding the segmented character of Latin America's social policy, few studies define it clearly, let alone suggest exact ways to measure it. This article provides a more precise definition based on a threefold policy output made of coverage, generosity and equity. Empirically, the paper explores the cross-national variation in segmentation in health care within Latin America in 2000 and 2013, before and after Latin America's economic boom. The article clusters countries, evaluate which ones improved their relative position during the 2000s, and determine the overall level of segmentation in the region. Findings are twofold. First, we identify three clusters: countries that respectively do particularly well and poorly across policy dimensions in 2000 and 2013, and a smaller set of countries that improved significantly, particularly regarding coverage and generosity. Secondly, despite cross-national differences, there are shared regional challenges - the risk of catastrophic expenditure being a case in point. Our analysis demonstrates the need to move beyond coverage as a policy goal and pay more attention to gaps in generosity in every country. We also call for better indicators to measure performance beyond coverage across countries and more studies that explain the similarities and differences between countries that improved considerably during the 2000 s.
\end{abstract}

\section{Keywords}

Social policy, segmentation, health care, Latin America. 


\section{Introduction}

Much has been written about the high level of social policy segmentation in Latin America. Some authors have characterized the region's welfare state as "truncated", stressing the lack of rights for large segments of the population and the existence of multiple programs with unequal characteristics. Others have highlighted the differences in policy outputs (e.g. quality of services, level of transfers) enjoyed by different social groups (Mesa Lago 1978, Filgueira 1998). Yet paradoxically few studies provide a clear definition of segmentation or suggest exact ways to measure it. This paper fills this gap in the literature, building on a definition of segmentation as a policy output. Segmentation takes place when a significant amount of people is not sufficiently protected from market forces in a particular social policy realm (such as health care or pensions) or when this protection is uneven among different groups. We thus approach segmentation as a threefold policy output that includes coverage, generosity and equity (Martínez Franzoni and Sánchez-Ancochea 2016a). Rather than as a binary category, we measure it along a continuum from low to high.

Empirically, the paper explores the cross-national variation in segmentation in health care within Latin America in two moments, 2000 and 2013. Our aim is threefold: cluster countries with similar characteristics in the three dimensions of segmentation, evaluate which countries have improved their relative position during the $2000 \mathrm{~s}$, and determine the overall level of segmentation in the region. [1] We focus on health care because it is the largest social program in almost every country and affects all citizens at every stage of their lives. We select 2000 and 2013 to measure the impact of the expansionary phase of social policy in the region. 
Below we first discuss the meaning of segmentation followed by a review of the literature on Latin America's cross national variation in terms of social policy during the last century. Section 4 presents our methodology based on cluster analysis and discusses the selected indicators. Section 5 reports clusters of countries with more or less segmentation in each of the relevant dimensions before the expansionary phase. Section 6 presents the cross-national performance in terms of coverage, generosity and equity in 2013, comparing it with 2000 . We show that a set of high and low performing countries maintained their relative position across time. Four others (Colombia, Mexico, Peru and, to a lesser extent, Ecuador) jumped to better clusters thanks to improvements across the three dimensions. We conclude by summarizing our findings and drawing implications for future research.

\section{The meaning of segmentation}

From the onset, state intervention in the social realm in Latin America was organized around the Bismarckian insurance model (Mesa Lago 1978, Barrientos 2009, Antía, Castillo and Midaglia 2015). Formal salaried urban workers and their families were protected under a number of funds based on payroll contributions. Everyone else was less protected or totally marginalized.

Many authors have used the term segmentation to refer to these arrangements. For example, Molyneux (2009) describes Latin America as having "weak and segmented social protection" (Molyneux 2009, 786). In an earlier exploration of the welfare systems in Latin America's most developed countries, Huber (1995) contrasts segmentation to universalism, arguing that "if a [social] model is set up with segmented and unequal programmes, it will be very difficult to reorient it later in a universalistic and egalitarian direction" (p. 37, italics added). 
In this literature segmentation is used in two related but different ways. On the one hand, the concept is meant to depict compartmentalized social programs-with more than one point of entry — within the same policy realm. For example, health care is segmented when there are institutionally separated social insurance and social assistance programs. This is clearly how Barrientos (2011) uses the term when he argues that "the spread of social assistance might have reduced the truncated nature of social protection, but this has been achieved by exacerbating segmentation. In most countries, social assistance is being institutionalized separately from social insurance" (Barrientos 2011, 14).

On the other hand, segmentation is often understood as an outcome of social policy interventions. This seems to be the case in a recent book published by the Economic Commission for Latin America and the Caribbean (ECLAC) when arguing that "although large gaps remain, efforts to extend population coverage are taking centre stage, and there is a growing movement to reduce segmentation in the quality of and access to social protection policies" (Ceccini, Filgueira, Martínez \& Rossel 2015, italics added). [2]

These two meanings are often conflated. In a well-known critical approach to targeting, Mkandawire seemingly addresses segmentation both to depict programs and their results: "targeting itself almost by definition leads to segmentation and differentiation. In service provision, targeting leads to the creation of a dual structure - one aimed at the poor and funded by the state, and one aimed at the wellto-do and provided by the private sector. Or, as Amartya Sen argues, "benefits meant exclusively for the poor often end up being poor benefits" (Mkandawire 2005, 7, italics added). [3] 
The two definitions are obviously related: the existence of different programs will likely lead to unequal results as well. Nevertheless, they refer to two different levels of analysis. Fragmentation in areas like health care or pensions can result from multiple reasons, including the existence of several social insurance funds, the exclusive concentration of public interventions on the poor or the existence of separate social insurance and social assistance instruments. Each source of fragmentation will result in different policy outputs in terms of coverage and generosity.

In this article, we use the term segmentation to refer to the outputs of social policy. We approach segmentation in opposition to universalism as two ends of a continuous multidimensional variable — a point Pribble (2013) has also emphasized. These dimensions measure complementary aspects of protection from the market: universalism takes place when all individuals are fully protected from market forces in the social realm, while segmentation is evident when a significant amount of people still depend on the market and lack proper protection.

Segmentation can be defined along three main dimensions (Martínez Franzoni \& Sánchez-Ancochea 2016a; 2016b). The first is coverage defined as the proportion of people who has effective access to benefits. The second is generosity that qualifies the type of access people get. Generosity has to do with how comprehensive services are and with their quality. In this paper, we do not assess generosity against an ideal maximum but, instead, define it in relative terms, across countries. The third dimension is equity and refers to how well distributed access and generosity are among different income groups. In terms of the three dimensions, segmented outputs involve uneven coverage and/or generosity between different groups. 


\section{Segmented social policy and cross national variations}

While the problem of segmentation in policy outputs has been prevalent across Latin America, historically the region has presented significant cross-national variations (Filgueira 1998). Throughout the second half of the $20^{\text {th }}$ Century, countries in the Southern Cone (together with Costa Rica since 1970) outperformed the rest of Latin America in both coverage and the generosity of services. In contrast, in the Andean countries and the rest of Central America, health coverage was low and access to basic services uneven. Brazil and Mexico resembled the successful cases in urban areas and the under-achievers in rural ones.

During the 1980s and 1990s, pro-market reforms transformed state intervention in social policy (Filgueira 2007, Mesa Lago 2007). Under the neoliberal turn, international financial institutions and many governments redefined social risks as an individual matter to be privately managed. Social programs were to focus on the poor (Rudra 2007, Haggard and Kaufman 2008). These changes did little to reduce segmentation: inequalities in the quality of services within the middle class added a new layer of segmentation across the region. Additionally, the expansion of state social programs that reached the poor was uneven in coverage, generosity and continuity.

Once again, this regional pattern hid significant cross-national differences, which have been explored by a number of authors (Table 1). Unfortunately, none of these studies focus explicitly on the level of segmentation, paying little attention to generosity and even less to inequalities between individuals. Yet given their attention to coverage and spending, they are still a useful starting point for our own exploration. Most studies converge around three intra-regional groupings: high achievers, including Argentina, Chile, Costa Rica, and Uruguay; low achievers, 
involving, Paraguay and the Andean and Central American countries except Costa Rica; and cases that had features of both, namely, Brazil, Mexico and, for some studies, Panama.

[Table 1 Here]

The region experienced significant changes in social policy during the 2000s (ECLAC 2014). Electoral competition together with the commodity boom and the move to the left renewed attention to interventionist social policies (Cameron, Hershberg \& Beasley-Murray 2010; Garay 2016; Huber \& Stephen 2012; Reygadas \& Filgueira 2010; Weyland, de la Madrid, \& Hunter 2010). There were at least three significant innovations across the region. First, all countries but Venezuela created conditional cash transfers (CCTs) aimed at reducing inter-generational poverty (Stampini \& Tornarolli, 2012). Second, in health care and pensions contributory schemes were reformed and non-contributory programs created or expanded (Mesa Lago 2007, OCDE, World Bank and IDB 2015). Third, in response to demographic changes and the rapid increase in women's access to the labour force, Latin American countries introduced new care programs, mostly for young children (Berlinski and Schady 2015).

As a result, resources allocated to social policy expanded: spending as percentage of GDP was seven points higher in 2013 than in 2000, while per capita spending increased even more (see Figure 1). This renewed effort concentrated primarily in transfers (which increased by 3.1 percentage points), but spending in education (1.1) and health care (1.2) also grew (ECLAC 2014). 
Did these new resources result in lower segmentation in social policy? Have they changed the clustering of countries? Few studies have aimed to answer these questions or used a sufficient number of indicators. For example, Ocampo \& Gómez Arteaga (2016) evaluate the performance of social protection in Latin America during the 2000 s, but focus exclusively on universality in coverage of health and pensions, solidarity (i.e. coverage of low income groups) and social spending. Combining these dimensions, they build a social protection score (SPS) to compare the evolution of all Latin American countries. They identify three different groups: comprehensive SPS (Uruguay, Chile, Costa Rica, Argentina and Brazil), intermediate SPS (Venezuela, Colombia, Peru, Mexico, Ecuador, Dominican Republic and Panama) and limited SPS (El Salvador, Paraguay, Bolivia, Nicaragua, Guatemala and Honduras).

Because we are interested in studying segmentation, coverage and spending are relevant yet insufficient mesures: higher coverage may result into different degrees of overall segmentation depending on whether the quality of the services and the generosity of transfers change and for whom. In considering a larger number of variables, our analysis is closer to Sojo (2017)'s excellent study of the current state of social protection in Latin America. She regards fragmentation and segmentation as fundamental shortcomings in the region and evaluates changes in coverage in the aggregate and among different income groups. Yet our study goes further in the comparative analysis of segmentation by making a more explicit distinction between its three dimensions, incorporating additional indicators and identifying clusters.

\section{Methodology}

The paper aims to evaluate the changes in health policy during the 2000s in terms of policy outputs, focusing on the level of segmentation. As discussed in Section 2, we 
consider this concept across three dimensions: coverage, generosity in level and quality, and equity.

We focus on health care because it is the one policy sector that affects people from cradle to crave. It is thus one of the most fundamental for people's lives and one where reliance on the market can be particularly harmful (Krishna 2011; WHO 2010). In addition, along with pensions, health care is on one of the largest social programs in Latin America (ECLAC 2018).

To evaluate changes in segmentation in these three dimensions, we consider a set of proxy measures for two moments, 2000 and 2013. [4] We chose data available for the largest number of countries from a larger database with 295 indicators drawn from international sources. [5] In all cases we rely on reputable databases that provide authoritative and comparable cross-national data.

[Table 2 Here]

Measuring coverage of public health services is tricky: most countries have a public health pillar so that in theory all citizens have free access to health care. Nevertheless, real access is more limited and its measurement requires the use of proxies. For example, Pribble (2011) addresses access indirectly through a set of outputs, including neo-natal mortality rate and mortality before five-years of age triggered by diarrhoea and pneumonia. Yet these measures also reflect the generosity of the system - a dimension we want to consider separately. Instead, we use coverage of health insurance as a proxy since data for public health is patchy and inconsistent. We break health insurance between salaried and non-salaried or self-employed 
workers. [6] Our indicator of coverage is not without problems. It overlooks differences in access to non-contributory public health (where countries like Argentina perform particularly well) and fails to include countries without insurance programs (i.e. Brazil and Cuba). Indeed, creating a better comparative measurement of access to health care should be a primary concern for regional and international institutions like ECLAC and the WHO.

For generosity, spending — measured as percentage of the GDP — is a well-established proxy measure to public effort and commitment. It is hard to have high quality, comprehensive benefits with a low amount of resources devoted to health care. Of course, spending is an insufficient indicator of generosity because resources can easily be wasted or spent on the wrong priorities. For this reason, we also include indicators that consider basic and complex medical procedures. To measure the former, we use births attended by a skilled professional and neonatal mortality rate. The latter is the number of neonates dying before reaching 28 days of age, per 1,000 live births in a given year. It directly reflects prenatal, intrapartum, and neonatal care. [7]

Access to complex procedures is measured by the risk of catastrophic expenditures and antiretroviral therapy coverage. The risk of catastrophic expenditure (only available for 2013) is defined as the probability that surgical care represents a cost above $10 \%$ of household expenditure per year. Antiretroviral therapy indicates the percentage of all people living with HIV who receive antiretroviral therapy. It is a useful indicator to consider how quickly public health care has responded to new risks in different countries. We searched extensively for proxies of service quality such as waiting lists, but could only find data for a handful of countries. 
To measure equity, we first consider private health spending as percentage of GDP as an indicator of the commodification of health care. A highly commodified health provision will lead to inequalities in health rights between the wealthy and the rest of the population (Martínez Franzoni and Sánchez-Ancochea 2017). Private health spending is thus reflecting more than an input measure and it provides a meaningful proxy to equity in generosity. High private spending reflects weaknesses in public benefits which lead people to search for other options. Ideally we would also include gaps in actual benefits (e.g. cancer treatment per quintile) as well as on waiting lists to measure the equity in the two dimensions of generosity (i.e. type and quality). Regrettably, at the moment additional indicators are only available for a few countries. Secondly, we look at coverage gaps in insurance between the lowest and highest quintiles for salaried and non-salaried workers. We also consider the situation of domestic workers who are among the least protected groups in the labour force.

We used factor analysis to make sure that we were dealing with a set of variables that added explanatory capacity to our model. We also used it to confirm that our variables relate to different dimensions. The fitness of each indicator to reflect each dimension, however, has more to do with analytical criteria than with statistical fitness.

Using these indicators, we conduct a cluster analysis to identify similar countries and separate them from dissimilar ones for two years, 2000 and 2013. We use hierarchical clustering which begins with all units of observation as members of a single cluster and proceeds to disaggregate most dissimilar cases (as opposes to departing from a pre-defined number of clusters). The method to allocate cases to clusters is single linkage, which establishes the shortest distance between two points in each cluster. 


\section{Segmentation in health care before the expansionary phase}

We begin our cluster analysis by providing a regional picture for 2000 as a comparative baseline. Our purpose is twofold: (a) to explore how countries clustered in each of the three dimensions of segmentation; and (b) to evaluate the overall level of segmentation in the region.

\section{Coverage}

By 2000, three countries (Chile, Costa Rica and Uruguay) performed well above the average in terms of social insurance coverage. Argentina and Panama constituted a second group with high coverage among salaried workers but a lower inclusion of the self-employed. In all other countries, health insurance failed to include more than half of the population (Table 3 ).

[Table 3 Here]

\section{Generosity}

The best performing countries in terms of generosity are the same than in coverage (see Figure 2). In 2000, Chile, Costa Rica and Uruguay excelled in basic procedures (e.g. almost all births were attended by skilled health professionals) and had begun meeting new challenges (Table 4). They also spent as an average more than any other country in the region. Argentina and Panama constituted a second group with a comparatively good yet uneven performance.

[Figure 2 Here] 
When considering generosity, the rest of the countries split into two groups. Five countries (Bolivia, Guatemala, Honduras, Paraguay and Peru) performed poorly across the board. In contrast, a second group including Colombia, Ecuador, El Salvador, Mexico and Nicaragua performed well in some areas (e.g. deliveries attended by skilled personnel), but was rather weak in others.

[Table 4 Here]

\section{Equity}

The number and composition of clusters for equity are the same than for coverage (Table 5). In this dimension, the differences between the best and worst performers are particularly striking. In Costa Rica, Chile and, particularly Uruguay, coverage is almost universal, regardless of people's level of income and occupation. In contrast, the distribution of coverage is very unequal in many other parts of the region. Even in Colombia — one of the best performing countries within the bottom group — health care coverage for domestic workers was just one fourth of that for public employees. In countries like Guatemala and Honduras, low-income groups were excluded from health insurance altogether.

[Table 5 Here]

Summary 
When considering health care segmentation, in 2000 there were significant

differences between the three best performing countries and the rest (see Table 6 for summary rankings). In Chile, Costa Rica and Uruguay, most of the population had access to public health care in the form of social insurance and fully covered basic services. New procedures like antiretroviral therapy for people living with HIV had also been introduced - a positive innovation that was also observable in Argentina. The system was also relatively equitable.

The rest of Latin America (with the exception of Argentina and Panama) stood in stark contrast. All countries had uneven coverage, particularly for the self-employed, and unequal access depending on income and occupation. There was more diversity in terms of generosity: some countries provided some basic services (e.g. attended births) to a majority of the population and also had a relatively high level of public spending. Yet even in those cases, neonatal mortality rates were high-signaling in part weaknesses in the quality of institutional birth deliveries —and complex procedures were not covered.

[Table 6 Here]

\section{Segmentation and clustering after the expansionary phase}

As discussed in previous sections, since 2000, the region experienced significant innovations, most of which reversed the previous state-rollback. Several countries created tax-funded insurance systems either for everyone without access to contributory programs or for vulnerable groups. Did all these changes contribute to significant movements away from segmentation? Do we see systematic differences 
between countries? Below we answer these questions by exploring how countries clustered by dimension in 2013 .

\section{Coverage}

Access to health care increased across the region during the 2000 s, benefiting both salaried and non-salaried workers (and, indirectly, their families). Figure 3 compares direct access to health insurance for each set of workers in 2000 and 2013. The furthest to the left a country is located, the largest its improvement during the $2000 \mathrm{~s}$. Colombia, Mexico and Peru expanded coverage particularly fast, mainly thanks to the creation of subsidized insurance programs and, to a lesser extent, to the formalization of labor relations. Figure 2 also shows large gaps between countries and between salaried workers and the self-employed within most countries.

\section{[Figure 3 Here]}

The new clusters clearly reflect the improvements of Colombia, Mexico and Peru. Colombia joins the best performing cluster, together with Chile and Uruguay. The rapid incorporation of self-employed workers to public health insurance was particularly impressive. Peru and Mexico join Costa Rica and Argentina as part of a cluster with an average coverage of three fourths of the salaried earners and two thirds of the self-employed workers. Costa Rica's "downgrade" from the top group to this one is a signal of its growing problems to provide free health care for the whole population since the late 1980s (Martínez Franzoni and Sánchez-Ancochea 2016a). Panama and Ecuador constitute a third cluster — absent in 2000 - made of countries with relatively high coverage for salaried workers but persistent low coverage for 
others. The expansionary phase influenced the two countries differently: Ecuador secured services for new groups, while Panama remained stagnant.

Finally, in the rest of the region coverage remained low. Except in Bolivia, countries experienced very small progress during 2000s: more than half of salaried workers and almost $90 \%$ of self-employed workers continued marginalized.

[Table 7 Here]

\section{Generosity}

Here, we introduce the risk of catastrophic expenditure as a new variable to our model. Although its consideration makes the analysis slightly different to 2000, it adds a valuable proxy measure of the availability of complex procedures.

The analysis reports four clusters (see Table 8). The best performers include the same as in 2000 together with Colombia and Mexico. This group does comparatively better than the rest in all indicators except antiretroviral therapy, where Argentina is the leading country. The worst performers - i.e. those with the highest level of segmentation in generosity_-includes Bolivia, Guatemala, Honduras, Nicaragua and Paraguay. Two middle groups (one with Argentina and Peru and the other with Ecuador, Panama and El Salvador) have a similar performance.

[Table 8 Here]

When comparing 2000 and 2013 in terms of generosity, there are three major changes. First, Mexico and Colombia improve in all four indicators. For example, Colombia increased almost nine percentage points the share of births attended by 
skilled staff, the neonatal mortality decreased by four percentage points and antiretroviral therapy coverage went from 0 to $39 \%$.

Second, Peru is another star performer, with significant jumps in all dimensions and a move from the bottom cluster to a middle one. Nevertheless, Peru has room for improvement in several areas: public spending as percentage of GDP is just 3\% and the risk of catastrophic expenditure affects $36 \%$ of the population.

Third, basic procedures expanded across the board. For example, among the worst performing countries, the percentage of births attended by skilled personnel increased by 25 percentage points and neonatal mortality decreased by more than six percentage points. Yet the generosity of health care provision in these left behind countries still shows significant shortcomings: more than half of the people is at risk of catastrophic expenditure and less than $30 \%$ of people living with HIV receive antiretroviral therapy.

\section{Equity}

When considering the dimension of equity, there are also four clusters. The best performers of 2000 together with Colombia are at the top. The only negative trend in this group is the growing levels of private spending in Chile and Costa Rica, which constitutes an emerging threat to the public sector (Martínez Franzoni and SánchezAncochea 2017). At the opposite end of the spectrum, we have the five left-behind countries (El Salvador, Guatemala, Honduras, Nicaragua and Paraguay), where no significant improvements in equity can be observed. In these countries, large segments of the poor remain excluded from an already weak public sector. 
The two groups in the middle include countries with diverse trajectories in the 2000s: Argentina and Panama were doing relatively well in the early 2000s and do not show consistent improvements. Some would argue that Argentina's coverage gap result from the fact that low income groups use non-contributory public services that are comparatively of high quality. This may be partly the case but Argentina's total public spending is not particularly high and actually decreased in recent years. In contrast to Argentina and Panama, in Mexico and Peru and, to a lesser extent, in Ecuador and Bolivia, the incorporation of low-income groups to health insurance constitutes a new trend.

[Table 9 Here]

Two other changes are worth mentioning. The evolution of private spending reflected in Figure 4 was rather uneven. It increased significantly in some countries, particularly among the bottom group. Yet in cases like Argentina, El Salvador and Uruguay, expenditure in this outside option decreased significantly. [8] Explaining these different patterns of private spending constitutes a challenge that requires more attention to country-based data (Sánchez 2014)

[Figure 4 Here]

The evolution of private spending together with the evidence on unequal access to health insurance points to a vicious circle in the left behind countries - with the partial exception of El Salvador. In these countries coverage of health insurance is restricted to a small group of formal workers, which benefit unevenly from state intervention. In 
contrast, both the wealthy and the poor use private services, which show a significant variance in quality.

\section{Summary}

When we consider the combined results of the three dimensions in Table 10 and compare them to the clusters in 2000 a few interesting patterns emerge. The position of some countries at the top and at the bottom has not changed. Chile and Uruguay remain leading countries. Costa Rica's performance is also positive but well-known cracks in its health care system are evident in decreasing coverage and growing private spending. At the other end of the spectrum, Bolivia, Guatemala, Honduras, Nicaragua and Paraguay still show a consistent poor performance in all three dimensions - even if they have also improved in several indicators, particularly of generosity.

Colombia — which joined the best performers in all dimensions-Mexico and Peru stand out as the three countries that improved most. Colombia and Mexico introduced non-contributory arrangements during the 2000 s that led to improvements in all three dimensions of segmentation — even if cross regionals gaps in quality and coverage remain (M.E. \& Neilly 2013; Montenegro \& Acevedo 2013). In Peru, more attention to the low income population is behind the observed improvements, even if the incorporation of vulnerable occupations like domestic workers is uneven and the risk of catastrophic expenditure high.

In Ecuador coverage increased by 18 percentage points among salaried workers and 10 percentage points among the self-employed. The reduction of the gap between low and high income groups and between domestic workers and public servants was also 
significant. Yet inequality remains high (with growing private spending) and there are also challenges in generosity.

[Table 10 Here]

\section{Conclusions}

Many authors identify segmentation as a primary characteristic of social policy in Latin America. The term has been applied to a diversity of problems, including uneven access, program fragmentation, and inequality in benefits. Yet few studies have paid attention to its adequate definition or rigorous measurement.

This article constituted a first attempt to fill this gap in the literature. Departing from the distinction between two meanings of segmentation (one that characterizes social programs and other that refers to policy outputs), we proposed an output-based definition with three different dimensions: coverage, generosity and equity. Social policy in areas like health care results in segmented outcomes when coverage and generosity are low, and/or inequality is high. We placed segmentation and universalism at two extremes of a continuum and paid special attention to the measurement of each dimension.

The article explored variations across Latin America in terms of social policy segmentation. To do so, we undertook cluster analysis of coverage, equity and generosity for 2000 and 2013 in health care — one the largest social programs in terms of expenditure and reach.

We not only aimed to understand patterns of segmentation across the region but also to evaluate changes during the recent phase of expansionary social policy. During the 2000s, the much-heralded expansion of CCTs together with new non-contributory 
health care, provided services to people previously ignored (Levy \& Schady 2013). While many studies have explored the impact of CCTs, measured the reduction of income inequality or evaluated changes in specific countries, there are few systematic evaluations of the effects of the 2000 s on social policy segmentation.

We identify a small group of top performers (Chile, Costa Rica and Uruguay) that rank consistently high among policy dimensions both in 2000 and 2013. [8] In contrast, six countries did consistently poorly across time. Bolivia, El Salvador, Guatemala, Honduras, Nicaragua, and Paraguay showed low coverage, generosity and equity in 2000 and 2013. These countries did experience some positive changesparticularly in generosity and most significantly in the Salvadorian case. Nonetheless, they are still close to what (Gough \& Wood 2004) refer to as informal security regimes characterized by a patchy and unequal state presence.

The four countries whose relative position changed most within our sample are Colombia, Mexico, Peru and, to a lesser extent, Ecuador. Colombia deserves particular attention given its efforts to incorporate everyone to health care and reduce the benefit gap between contributory and non-contributory programs. Public spending as percentage of GDP increased rapidly, while private spending is one of the lowest in the region. Problems remain, particularly, in terms of generosity gaps between those that use private and public providers and between different regions of the country (Montenegro Torres \& Bernal Acevedo 2013), but the change has been impressive and deserves closer attention.

Despite cross-national differences, shared challenges remain across the region. Key indicators like the risk of catastrophic expenditure are particularly illustrative of lasting segmentation. This result is not surprising given Latin America's legacies, but 
demonstrate the need to move beyond coverage as a policy goal and pay more attention to gaps in generosity in every country.

Our findings have implications for future research agendas on Latin America's social policy and open - rather than settle - a new line of inquiry. For example, research in comparative political economy should explore the similarities and differences between the countries that improved their ranking. Were the policy changes in Colombia, Mexico, Peru and Ecuador similar? What were the political factors behind the various reforms? We should also pay more attention to the vicious circles that affect left-behind countries and make advances towards less segmentation particularly hard.

We are also aware of the need to develop better indicators. We need a more comprehensive measure of coverage that goes beyond health insurance and considers effective access to non-contributory public health care-which is dominant in countries like Brazil or, to a lesser extent, Argentina. International institutions should also pay more attention to how to measure generosity - e.g. measures of access to life threatening conditions like cancer and of waiting lists — equity—relative coverage of key procedures — and the role of the private sector. Filling these voids would help identify future challenges, moving policy and analysis away from an exclusive focus on access and spending. This will not only improve academic understanding but will also provide inputs to design effective policy reform in the future.

\section{Notes}


We are grateful to Cecilia Giambruno for assisting us in putting together the statistical data base. We thank Carmen Midaglia and participants in seminars organized by Barbara Fritz in Germany and Gibran Cruz Martínez in Norway as well as to two referees for useful comments in previous drafts. CAF-Development Bank of Latin America provided much needed funding support within the LAC-CAF agreement.

1. Lack of data forced us to exclude Brazil, Cuba Dominican Republic and Venezuela from the analysis.

2. The literature on labour markets and social policy in OECD offers a third meaning. Scholars relate a set of inequalities in income, mobility and training to a set of inequalities in social protection (e.g. Häusermann y Schwander 2010). The asymmetries between individuals in access and quality of social benefits results from a variety of factors related to labour supply (e.g. education) and to labour demand (e.g. flexible versus non-flexible labour arrangements).

3. The confusion between the two terms is also present in the specialized literature on health care in Latin America. In an influential paper in The Lancet, Cotlear et al (2014: 1) talk about segmentation of the health systems but also about segmentation in benefits and quality as policy outcomes.

4. When there is no data available for 2000 and 2013 , we use the closest (between 2000 and 2003 and between 2010 and 2013).

5. We are aware of the limitations of cluster analysis, including variance withinclusters.

6. Early neonatal deaths (0-7 days) are more closely associated with pregnancyrelated factors and maternal health, whereas late neonatal deaths (8-28 days) 
are associated more with factors in the new-born's environment. See

https://www.measureevaluation.org/prh/rh_indicators/womens-

health/nb/neonatal-mortality-rate-nmr

7. In Uruguay, the reduction of private spending does not reflect changes in the outside private option as much as the impact of the 2007 health reform. This policy reform pulled all the contributions made to mutual funds into a single fund managed by the public sector.

8. Argentina did not experience many changes in the 2000 s either. It was in a middle group close to the top performers in 2000 and remained in a similar position in 2013.

\section{Bibliography}

Antía, Florencia, Marcelo Castillo, and Carmen Midaglia. 2015. La estratificación como reto para los ajustes de los sistemas de bienestar. Revista latinoamericana de investigación crítica 3: 101-135.

Barrientos, Armando. 2009. Labour markets and the (hyphenated) welfare regime in Latin America. Economy and Society 38: 87-108.

Barrientos, Armando. 2011. On the Distributional Implications of Social Protection Reforms in Latin America. Working Paper 2011/69, UN-WIDER .

Berlinski, Samuel, and Norbert Schady. 2015. Los primeros años: el bienestar infantil y el papel de las poíticas públicas. New York: BID. 
Cameron, Maxwell, Eric Hershberg, and Jon Beasley-Murray. 2010. Latin America's Left Turns. Politics, Policies and Trajectories of Change. London: Lynn Rienner.

Ceccini, Simone, Fernando Filgueira, Rodrigo Martínez, and Cecilia Rossel. 2015. Towards universal social protection: Latin American pathways and policy tools. Santiago de Chile: ECLAC.

Cotlear, Daniel, Octavio Gómez-Dantés, Felicia Knaul, Rifat Atun, Ivana C H C Barreto, Oscar Cetrángolo, Marcos Cueto, and others. 2014. Overcoming social segregation in health care in Latin America. The Lancet (doi: 10.1016/S0140-6736(14)61647-0) 385.

ECLAC. 2014. Compacts for Equality. Towards a Sustainable Future. Santiago: United Nations.

ECLAC. 2018. Latin America (19 countries): social expenditure of central government, 2000-2015. Database on Social Investment in Latin America and the Caribbean. Santiago de Chile, 05 de 03.

Filgueira, Fernando. 1998. El Nuevo Modelo de Prestaciones Sociales en América Latina: Residualismo y Ciudadanía Estratificada. Edited by Brian Roberts. Ciudadanía y Política Social, San José: FLACSO, 71-116.

Filgueira, Fernando. 2007. The Latin American social states: Critical juncture and critical choices. Edited by Yusuf Bangura. Democracy and Social Policy, New York: Palgrave/UNRISD, 136-163.

Garay, María Candelaria. 2016. Social Policy Expansion in Latin America, New York: Cambridge University Press. 
Gough, Ian and Geof Wood. 2004. Insecurity and Welfare Regimes in Asia, Africa and Latin America. New York: Cambridge University Press.

Häusermann, Silja, and Hanna Schwander. 2010. Varieties of dualization? Labor market segmentation and insider outsider divides across regimes Paper prepared for the Conference "The Dualisation of European Societies?" Green Templeton College, University of Oxford, January 14-16.

Haggard, Stephan, and Robert Kaufman. 2008. Development, Democracy, and Welfare States: Latin America, East Asia, and Eastern Europe. New Jersey: Princeton University Press.

Huber, Evelyne. 1995. Options for Social Policy in Latin America. Neo-liberal vs Social Democratic Models. Discussion paper 66, Geneva: UNRISD.

Huber, Evelyn, and John Stephen. 2012. Democracy and the Left: Social Policy and Inequality in Latin America. Chicago: Chicago University Press.

Krishna, Anirudth. 2011. One Illness Away: Why People Become Poor and How They Escape Poverty. Oxford: Oxford University Press.

Levy, Santiago, and Norbert Schady. 2013. Latin America’s Social Policy Challenge: Education, Social Insurance, Redistribution. Journal of Economic Perspectives 27: 193-218.

Martínez Franzoni, Juliana. 2008a. Welfare Regimes in Latin America: Capturing Constellations of Markets, Families, and Policies. Latin American Politics and Society 67-100.

Martínez Franzoni, Juliana. 2008b. Domesticar la incertidumbre en América Latina: mercado. San José: Editorial de la Universidad de Costa Rica/UNDP. 
Martínez Franzoni, Juliana, and Diego Sánchez-Ancochea. 2016a. The Quest for Universal Social Policy in the South: Actors, Ideas and Architectures. Cambridge: Cambridge University Press.

—. 2016b. Regímenes de bienestar en América Latina: tensiones entre universalización y segmentación. In Los estados de bienestar en la encrucijada: politicas sociales en perspectiva comparada, by Eloisa Del Pino and María Josefa Rubio Lara, 200-219.

Martínez Franzoni, Juliana and Diego Sánchez-Ancochea. 2017. Achieving Universalism in Developing Countries. UNDP, 2016 Human Development Report Background Paper.

Mesa Lago, Carmelo. 1978. Social Security in Latin America: Pressure Groups, Stratification and Inequality. Pittsburgh: University of Pittsburgh Press.

—. 2007. Reassembling Social Security: A Survey of Pensions and Health Care Reforms in Latin America. Oxford: Oxford University Press.

Mkandawire, Thandika 2005. Targeting and Universalism in Poverty Reduction. Geneva: UNRISD

Molyneux, Maxine. 2009. The 'Neoliberal Turn' and the New Social Policy in Latin America: How Neoliberal, How New? Development and Change 39 (5): $775-$ 787.

Montenegro, Fernando, and Oscar Acevedo. 2013. Colombia Case Study: The Subsidized Regime of Colombia's National Health Insurance System . Washington, DC: The World Bank.

Ocampo, José Antonio, and Natalie Gómez Arteaga. 2016. Social Protection Systems in Latin America: An Assessment. Geneva: ILO. 
OCDE, World Bank, and IDB. 2015. Panorama de las Pensiones:América Latina y el Caribe.

Pribble, Jennifer. 2011. World Apart: Social Policy Regimes in Latin America. Studies in Comparative International Development 46: 191-216.

-. 2013. Welfare and Party Politics in Latin America. Cambridge: Cambridge University Press.

Reygadas, Luis, and Fernando Filgueira. 2010. Inequality and the Incorporation Crisis: The Left's Social Policy Toolkit. Edited by Cameron Maxwell A. and Eric Hershberg. Latin America's Left Turns: Politics, Policies and Trajectories of Change. Boulder: Lynne Rienner, 171-192.

Rudra, Nita. 2007. Welfare States in Developing Countries: Unique or Universal? The Journal of Politics 69: 378-396.

Sánchez, David. 2014. Consumo efectivo de los hogares en Salud. Serie Estudios Estadísticos (CEPAL) 83.

Segura-Ubiergo, Alex. 2007. The Political Economy of the Welfare State in Latin America. Cambridge: Cambridge University Press.

Sojo, Ana. 2017. Protección social en América Latina: la desigualdad en el banquillo, Santiago: CEPAL.

Stampini, Marco, and Leopoldo Tornarolli. 2012. The Growth of Conditional Cash Transfers in Latin America and the Caribbean: Did They Go Too Far? Vol. 185. Washington, DC,: Inter-American Development Bank.

Weyland, Kurt, Raul de la Madrid, and Wendy Hunter. 2010. Leftist Governments in Latin America. Cambridge: Cambridge University Press. 
World Health Organisation. 2010. World Health Report 2010: Health Systems

Financing: the Path to Universal Coverage. Geneva: World Health

Organisation 
Table 1. Typologies of Latin America's social policy from 1980s onwards

\begin{tabular}{|c|c|c|c|c|c|}
\hline Author & Criteria & Methodology & Period & Classification & $\begin{array}{c}\text { Indicators/treatment of } \\
\text { segmentation as a policy } \\
\text { output }\end{array}$ \\
\hline Filgueira (2007) & $\begin{array}{l}\text { Spending and coverage in } \\
\text { health care, social insurance } \\
\text { and education }\end{array}$ & $\begin{array}{l}\text { Descriptive } \\
\text { analysis of the } \\
\text { changes since } \\
\text { the } 1970 \text { s }\end{array}$ & $1990 \mathrm{~s}$ & $\begin{array}{l}\text { Stratified universalism } \\
\text { (Southern Cone and Costa } \\
\text { Rica); dual (Brazil and } \\
\text { Mexico); exclusionary (the } \\
\text { rest) remain from previous } \\
\text { period with changes on a } \\
\text { few countries (e.g. Chile). }\end{array}$ & $\begin{array}{l}\text { Coverage and benefits in } \\
\text { vaccination and social } \\
\text { insurance }\end{array}$ \\
\hline $\begin{array}{l}\text { Huber \& Stephen } \\
\qquad(2012)\end{array}$ & $\begin{array}{c}\text { Social spending and } \\
\text { coverage in pensions, health } \\
\text { care and education (and } \\
\text { political dimensions as } \\
\text { dependent variables) }\end{array}$ & $\begin{array}{c}\text { Econometric } \\
\text { analysis }\end{array}$ & 1980 & $\begin{array}{l}\text { Social states (Argentina, } \\
\text { Brazil, Chile, Costa Rica } \\
\text { and Uruguay); Mexico, } \\
\text { Panama and Venezuela; } \\
\text { and the rest }\end{array}$ & $\begin{array}{l}\text { Coverage, spending and } \\
\text { type of social spending } \\
\text { (human capital; social } \\
\text { protection) }\end{array}$ \\
\hline $\begin{array}{l}\text { Martínez Franzoni } \\
\text { (2008a and 2008b) }\end{array}$ & $\begin{array}{l}\text { Commodification, } \\
\text { decommodification, }\end{array}$ & Cluster analysis & 1999-2004 & $\begin{array}{l}\text { State productivist regime } \\
\text { (Argentina and Chile); state }\end{array}$ & $\begin{array}{l}\text { Coverage, spending, } \\
\text { rural/urban gaps and }\end{array}$ \\
\hline
\end{tabular}


defamiliarization and

performance of welfare

regimes

Pribble (2011)

$\begin{array}{cc}\begin{array}{c}\text { Distinguishes between risk } \\ \text { prevention (health care, }\end{array} & \begin{array}{c}\text { Cluster analysis } \\ \text { and }\end{array} \\ \text { (contributory and non- } & \text { historical } \\ \text { contributory pensions). } & \text { analysis } \\ \text { Focuses on coverage. In } & \\ \text { healthcare coverage is } & \\ \text { measured by outputs like } & \\ \text { neonatal mortality rate }\end{array}$

protectionist regime

(Brazil, Costa Rica,

Mexico, Panama and

Uruguay); informal-

familiarist (the rest of the

region)

Late
1990s-
early 2000s

High risk coping and risk prevention (Argentina,

Chile, Costa Rica and

Uruguay); medium risk

prevention-high risk coping

(Brazil, Mexico and

Panama); medium risk prevention-low risk coping (Peru, Colombia, Ecuador and Paraguay); low risk prevention and coping

(Dominican Republic, El

Salvador, Guatemala and Nicaragua) measures of policy outputs

(e.g. human capital)

\section{Effective coverage in} education, health care and pensions 


\begin{tabular}{|c|c|c|c|c|}
\hline $\begin{array}{l}\text { Segura-Ubiergo, } \\
2007\end{array}$ & $\begin{array}{c}\text { Spending in social spending } \\
\text { and health coverage }\end{array}$ & $\begin{array}{l}\text { Descriptive } \\
\text { statistics }\end{array}$ & $1973-2000$ & $\begin{array}{l}\text { Welfare states (Argentina, } \\
\text { Brazil, Chile, Costa Rica } \\
\text { and Uruguay) and non- } \\
\text { welfare states (the rest of } \\
\text { the region) }\end{array}$ \\
\hline
\end{tabular}


Figure 1. Public social spending in Latin America, 1990-2013

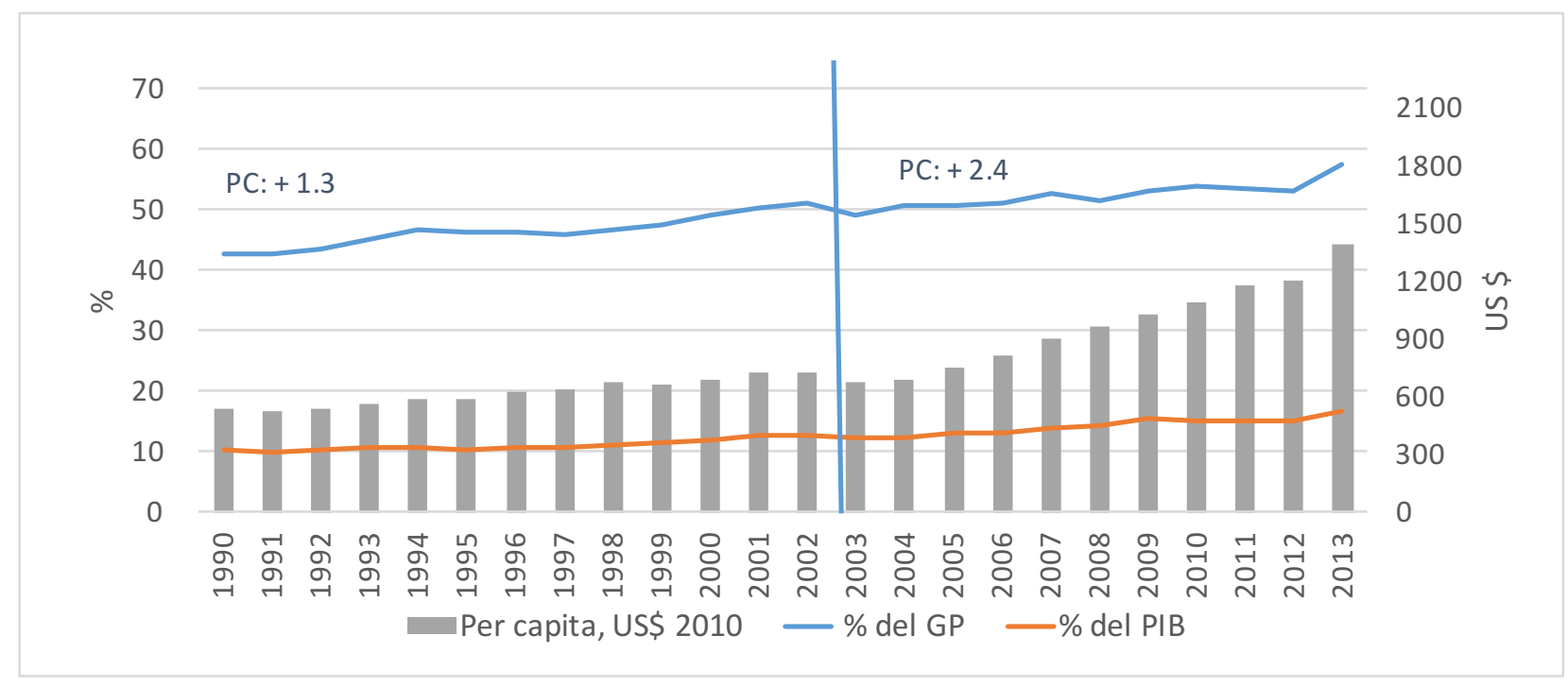

Sources: own elaboration with ECLAC data 
Table 2. Indicators of segmentation in health-care, 2000 and 2013

\begin{tabular}{|c|c|c|c|}
\hline $\begin{array}{l}\text { Dimension } \\
\text { and number } \\
\text { of indicators }\end{array}$ & Description of indicators & Source & Original source \\
\hline \multirow{2}{*}{$\begin{array}{l}\text { Coverage } \\
(2 \\
\text { indicators) }\end{array}$} & Coverage of salaried workers & Sojo 2017 & $\begin{array}{l}\text { Economic Commission for } \\
\text { Latin America (ECLAC) }\end{array}$ \\
\hline & $\begin{array}{l}\text { Coverage of non-salaried } \\
\text { workers }\end{array}$ & Sojo 2017 & ECLAC \\
\hline \multirow[t]{5}{*}{$\begin{array}{l}\text { Generosity } \\
(4 \\
\text { indicators) }\end{array}$} & $\begin{array}{l}\text { Public spending in health }(\% \\
\text { GDP) }\end{array}$ & $\begin{array}{l}\text { World Development Indicators, } \\
\text { World Bank }\end{array}$ & $\begin{array}{lll}\text { World Health } & \text { Organization } \\
\text { Global Health } & \text { Expenditure } \\
\text { database } & & \end{array}$ \\
\hline & $\begin{array}{l}\text { Births attended by skilled } \\
\text { personnel ( } \% \text { of all births) }\end{array}$ & $\begin{array}{l}\text { World Development Indicators, } \\
\text { World Bank }\end{array}$ & $\begin{array}{l}\text { UNICEF, State of the World's } \\
\text { Children, Childinfo, and } \\
\text { Demographic and Health } \\
\text { Surveys }\end{array}$ \\
\hline & $\begin{array}{l}\text { Neonatal mortality rate (per } \\
1000 \text { births) }\end{array}$ & $\begin{array}{l}\text { World Development Indicators, } \\
\text { World Bank }\end{array}$ & $\begin{array}{l}\text { Estimates developed by the UN } \\
\text { Inter-agency Group for Child } \\
\text { Mortality Estimation }\end{array}$ \\
\hline & $\begin{array}{l}\text { Risk of catastrophic } \\
\text { expenditure for surgical care } \\
\text { (\% of population at risk), only } \\
\text { for } 2013\end{array}$ & $\begin{array}{l}\text { World Bank, Health Nutrition } \\
\text { and Population Statistics }\end{array}$ & $\begin{array}{l}\text { The Lancet Commission on } \\
\text { Global Surgery }\end{array}$ \\
\hline & Retroviral therapy & World Bank & UNAIDS \\
\hline Equity & Private spending ( $\%$ GDP) & $\begin{array}{l}\text { World Development Indicators, } \\
\text { World Bank }\end{array}$ & $\begin{array}{lll}\text { World Health } & \text { Organization } \\
\text { Global Health } & \text { Expenditure } \\
\text { database } & & \end{array}$ \\
\hline
\end{tabular}




\begin{tabular}{|l|l|l|l|}
\hline indicators $)$ & $\begin{array}{l}\text { Workers with health insurance } \\
(\% \text { salaried workers) in the } \\
\text { lowest quintile (Q1) divided by } \\
\text { those in the highest quintile (Q5) }\end{array}$ & $\begin{array}{l}\text { Own elaboration with data from } \\
\text { Sojo (2017) }\end{array}$ & ECLAC \\
\cline { 2 - 4 } & $\begin{array}{l}\text { Workers with health insurance } \\
(\% \text { non-salaried workers) in the } \\
\text { lowest quintile (Q1) divided by } \\
\text { those in the highest quintile (Q5) }\end{array}$ & Sojo (2017) & ECLAC \\
\cline { 2 - 5 } & $\begin{array}{l}\text { Domestic workers with health } \\
\text { insurance (\% domestic workers) } \\
\text { / public workers with health } \\
\text { insurance (\% public workers) }\end{array}$ & Sojo (2017) & ECLAC \\
\hline
\end{tabular}

Source: Own elaboration 
Table 3. Indicators of coverage by cluster, 2000

$\begin{array}{cc}\text { Health insurance } & \text { Health insurance } \\ \text { (\% salaried } & (\% \text { self-employed }) \\ \text { workers }), & \end{array}$

$\begin{array}{lrr}\text { Guatemala } & 37.8 & 3.1 \\ \text { Honduras } & 36.0 & 0.9 \\ \text { Bolivia } & 29.8 & 7.8 \\ \text { Paraguay } & 33.2 & 9.7 \\ \text { Nicaragua } & 28.8 & 2.7 \\ \text { Colombia } & 53.2 & 14.3 \\ \text { El Salvador } & 50.0 & 10.6 \\ \text { Ecuador } & 45.0 & 13.4 \\ \text { Peru } & 39.3 & 14.2 \\ \text { Mexico } & 53.8 & 2.0 \\ \text { Average } & \mathbf{4 0 . 7} & \mathbf{7 . 9} \\ \text { SD } & \mathbf{9 . 3} & \mathbf{5 . 3} \\ & & \\ \text { Argentina } & 65.1 & 44.0 \\ \text { Panama } & 73.2 & 21.8 \\ \text { Average } & \mathbf{6 9 . 2} & \mathbf{3 2 . 9} \\ \text { SD } & \mathbf{5 . 7} & \mathbf{1 5 . 7} \\ & & \mathbf{7 9 . 6} \\ \text { Chile } & 92.1 & \mathbf{1 5 . 0} \\ \text { Costa Rica } & 83.7 & \\ \text { Uruguay } & 98.2 & \mathbf{7 9 . 3} \\ \text { Average } & \mathbf{7 . 3} & \\ \text { SD } & & \\ & & \\ & & \end{array}$

NOTE: based on dendrogram available upon request 
Figure 2. Dendrogram for generosity in 2000

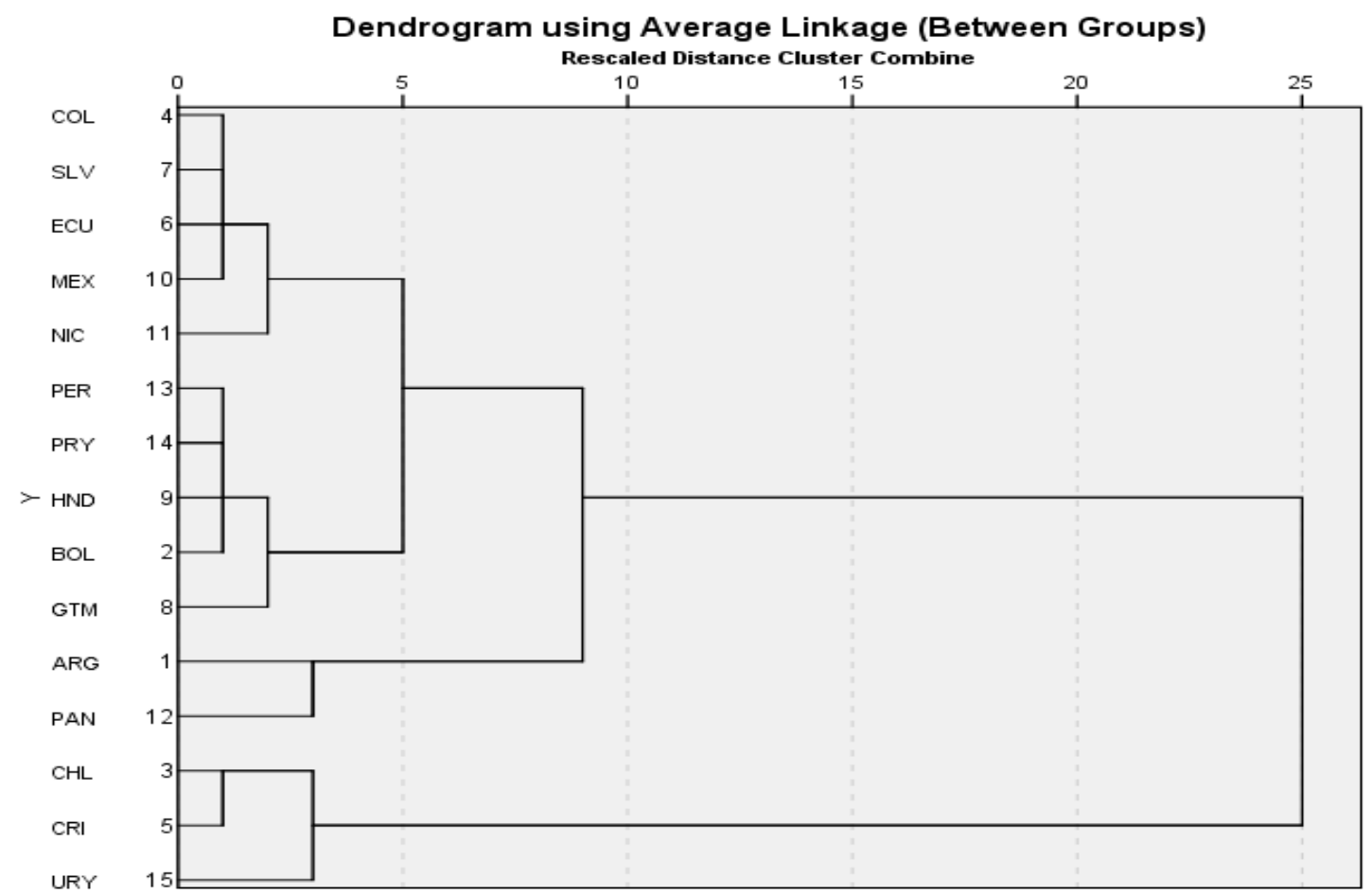

NOTE: we include just this dendrogram as an example of the type of output used for the clustering 
Table 4. Indicators of generosity by cluster, 2000

\begin{tabular}{|c|c|c|c|c|c|c|}
\hline Country & $\begin{array}{l}\text { Antiretroviral } \\
\text { therapy } \\
\text { coverage (\% of } \\
\text { people living } \\
\text { with HIV) } \\
\end{array}$ & $\begin{array}{l}\text { Health } \\
\text { expenditure, } \\
\text { public (\% of GDP) }\end{array}$ & $\begin{array}{l}\text { Births attended } \\
\text { by skilled health } \\
\text { staff (\% of total) }\end{array}$ & $\begin{array}{l}\text { Mortality rate, } \\
\text { neonatal (per } \\
1,000 \text { live births) }\end{array}$ & $\begin{array}{l}\text { Health insurance } \\
\text { (\% salaried } \\
\text { workers) }\end{array}$ & $\begin{array}{l}\text { Health insurance } \\
\text { (\% self employed) }\end{array}$ \\
\hline Colombia & 0.00 & \begin{tabular}{|l|}
4.68 \\
\end{tabular} & \begin{tabular}{|r|}
88.30 \\
\end{tabular} & 13.50 & \begin{tabular}{|l|}
53.20 \\
\end{tabular} & \begin{tabular}{|l|}
14.30 \\
\end{tabular} \\
\hline El Salvador & 0.00 & 3.80 & 90.40 & 14.40 & 50.00 & 10.60 \\
\hline Ecuador & 2.00 & 0.90 & 99.10 & 17.30 & 45.00 & 13.40 \\
\hline Mexico & 8.00 & 2.32 & 95.00 & 10.10 & 53.80 & 2.00 \\
\hline Nicaragua & 0.00 & 2.88 & 89.70 & 17.20 & 28.80 & 2.70 \\
\hline Average & 2.00 & 2.92 & 92.50 & 14.50 & 46.16 & 8.60 \\
\hline SD & 3.46 & 1.44 & 4.46 & 2.98 & 10.31 & 5.87 \\
\hline Peru & 0.00 & 2.72 & 62.50 & 15.80 & 39.30 & 14.20 \\
\hline Paraguay & 0.00 & 3.23 & 60.80 & 17.70 & 33.20 & 9.70 \\
\hline Honduras & 0.00 & 3.59 & 55.70 & 17.60 & 36.00 & 0.90 \\
\hline Bolivia & 0.00 & 3.25 & 68.80 & 29.90 & 29.80 & 7.80 \\
\hline Guatemala & 0.00 & 1.91 & 40.40 & 21.00 & 37.80 & 3.10 \\
\hline Average & 0.00 & 2.94 & 57.64 & 20.40 & 35.22 & 7.14 \\
\hline SD & 0.00 & 0.66 & 10.71 & 5.63 & 3.79 & 5.29 \\
\hline Argentina & 26.00 & 4.97 & 97.50 & 11.30 & 65.10 & 44.00 \\
\hline Panama & 9.00 & 5.28 & 90.00 & 14.70 & 73.20 & 21.80 \\
\hline Average & 17.50 & 5.13 & 93.75 & 13.00 & 69.15 & 32.90 \\
\hline SD & 12.02 & 0.23 & 5.30 & 2.40 & 5.73 & 15.70 \\
\hline Chile & 9.00 & 3.33 & 99.80 & 5.70 & 92.10 & 78.30 \\
\hline Costa Rica & 12.00 & 5.61 & 98.00 & 7.70 & 83.70 & 65.30 \\
\hline Uruguay & 24.00 & 2.71 & 99.60 & 8.40 & 98.20 & 95.20 \\
\hline Average & 15.00 & 3.89 & 99.13 & 7.27 & 91.33 & 79.60 \\
\hline SD & 7.94 & 1.53 & 0.99 & 1.40 & 7.28 & 14.99 \\
\hline
\end{tabular}


Table 5. Indicators of equity by cluster, 2000
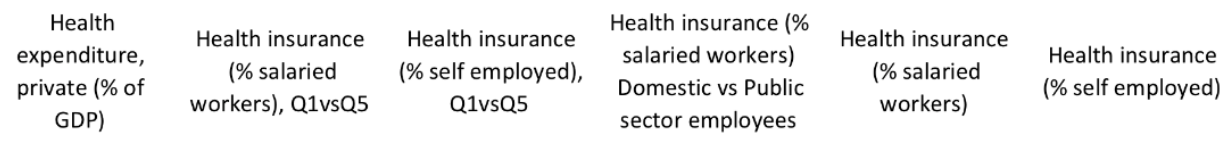

$\begin{array}{lrrrrrr}\text { Bolivia } & 2.4 & 19.9 & 8.5 & 8.2 & 29.8 & 7.8 \\ \text { Nicaragua } & 2.5 & 15.9 & 7.6 & 4.1 & 28.8 & 2.7 \\ \text { Guatemala } & 3.3 & 12.3 & 6.5 & 4.0 & 37.8 & 3.1 \\ \text { Honduras } & 3.0 & 1.1 & 0.0 & 3.2 & 36.0 & 0.9 \\ \text { Paraguay } & 4.9 & 4.8 & 5.6 & 9.7 & 33.2 & 9.7 \\ \text { El Salvador } & 4.4 & 9.1 & 5.7 & 7.0 & 50.0 & 10.6 \\ \text { Ecuador } & 2.5 & 25.8 & 13.3 & 12.4 & 45.0 & 13.4 \\ \text { Peru } & 2.1 & 20.0 & 15.5 & 16.1 & 39.3 & 14.2 \\ \text { Colombia } & 1.2 & 23.7 & 16.1 & 26.6 & 53.2 & 14.3 \\ \text { Mexico } & 2.7 & 21.0 & 19.4 & 12.2 & 53.8 & 2.0 \\ \text { Average } & \mathbf{2 . 9} & \mathbf{1 5 . 3} & \mathbf{9 . 8} & \mathbf{1 0 . 3} & \mathbf{4 0 . 7} & \mathbf{7 . 9} \\ \text { SD } & \mathbf{1 . 1} & \mathbf{8 . 3} & \mathbf{6 . 0} & \mathbf{7 . 1} & \mathbf{9 . 3} & \mathbf{5 . 3} \\ & & & & & & \\ \text { Argentina } & 4.2 & 22.4 & 21.8 & 43.1 & 65.1 & 44.0 \\ \text { Panama } & 2.5 & 49.9 & 17.9 & 30.5 & 73.2 & 21.8 \\ \text { Average } & \mathbf{3 . 4} & \mathbf{3 6 . 2} & \mathbf{1 9 . 8} & \mathbf{3 6 . 8} & \mathbf{6 9 . 2} & \mathbf{3 2 . 9} \\ \text { SD } & \mathbf{1 . 2} & \mathbf{1 9 . 5} & \mathbf{2 . 7} & \mathbf{8 . 8} & \mathbf{5 . 7} & \mathbf{1 5 . 7} \\ \text { Chile } & & & & & & \mathbf{7 8 . 3} \\ \text { Uruguay } & 4.6 & 94.7 & 112.1 & 93.6 & 92.1 & 95.2 \\ \text { Costa Rica } & 5.1 & 98.9 & 98.2 & 99.5 & 98.2 & 65.3 \\ \text { Average } & 1.5 & 68.8 & \mathbf{7 9 . 1} & 69.3 & 83.7 & \mathbf{7 9 . 6} \\ \text { SD } & \mathbf{3 . 7} & \mathbf{8 7 . 5} & \mathbf{9 6 . 5} & \mathbf{8 7 . 5} & \mathbf{9 1 . 3} & \mathbf{1 5 . 0}\end{array}$

NOTE: Based on dendrogram available upon request 
Table 6. Segmentation per dimension: countries' relative position, 2000

\begin{tabular}{|c|c|c|c|c|}
\hline Country & Coverage & \multicolumn{2}{|c|}{ Generosity } & Equity \\
\hline \multicolumn{5}{|l|}{ Uruguay } \\
\hline \multicolumn{5}{|l|}{ Chile } \\
\hline \multicolumn{5}{|c|}{ Costa Rica } \\
\hline \multicolumn{5}{|c|}{ Argentina } \\
\hline \multicolumn{5}{|l|}{ Panama } \\
\hline \multicolumn{5}{|l|}{ Mexico } \\
\hline \multicolumn{5}{|c|}{ Colombia } \\
\hline \multicolumn{5}{|l|}{ Ecuador } \\
\hline \multicolumn{5}{|c|}{ El Salvador } \\
\hline \multicolumn{5}{|c|}{ Nicaragua } \\
\hline \multicolumn{5}{|l|}{ Peru } \\
\hline \multicolumn{5}{|l|}{ Bolivia } \\
\hline \multicolumn{5}{|c|}{ Guatemala } \\
\hline \multicolumn{5}{|c|}{ Honduras } \\
\hline \multicolumn{5}{|c|}{ Paraguay } \\
\hline Coding & $\begin{array}{c}\text { Best } \\
\text { performers }\end{array}$ & Middle & cases & Left behind \\
\hline
\end{tabular}


Figure 3. Health care, coverage for salaried workers and self-employed workers, 2000 and 2013
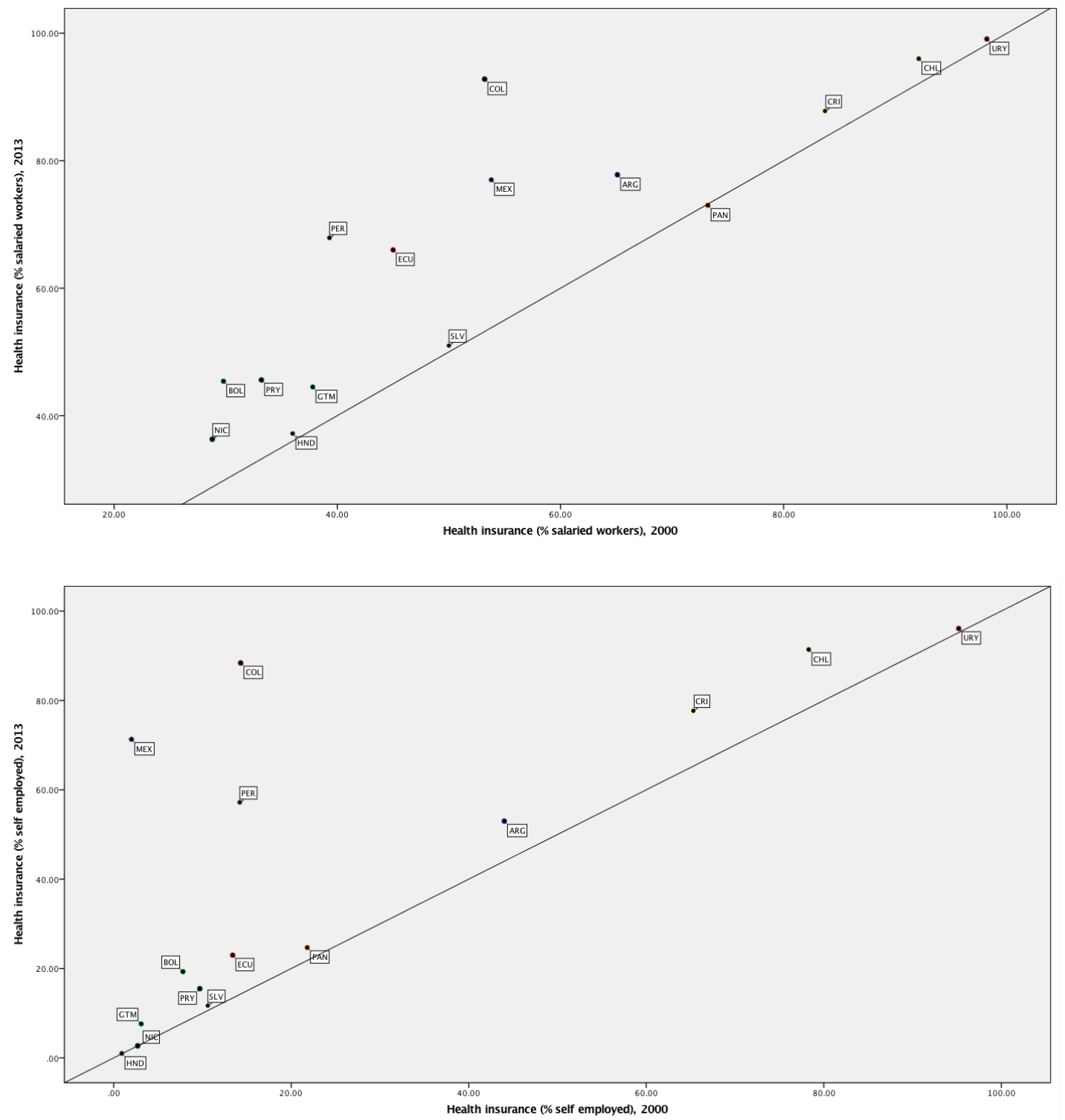

Source: own elaboration with data from Sojo (2017) 
Table 7. Indicators of coverage by cluster, 2013

\begin{tabular}{|c|c|c|}
\hline & $\begin{array}{l}\text { Health insurance } \\
\text { (\% salaried } \\
\text { workers) }\end{array}$ & $\begin{array}{l}\text { Health insurance } \\
\text { (\% self-employed) }\end{array}$ \\
\hline Honduras & 37.2 & 1.0 \\
\hline Nicaragua & 36.3 & 2.7 \\
\hline Bolivia & 45.4 & 19.3 \\
\hline Paraguay & 45.6 & 15.5 \\
\hline El Salvador & 51.0 & 11.7 \\
\hline Guatemala & 44.5 & 7.6 \\
\hline Average & 43.3 & 9.6 \\
\hline SD & 5.6 & 7.2 \\
\hline Ecuador & 66.0 & 23.0 \\
\hline Panama & 73.0 & 24.7 \\
\hline Average & 69.5 & 23.9 \\
\hline SD & 4.9 & 1.2 \\
\hline Chile & 96.0 & 91.4 \\
\hline Colombia & 92.8 & 88.4 \\
\hline Uruguay & 99.1 & 96.1 \\
\hline Average & 96.0 & 92.0 \\
\hline SD & 3.2 & 3.9 \\
\hline Argentina & 77.8 & 53.0 \\
\hline Peru & 67.9 & 57.2 \\
\hline Costa Rica & 87.8 & 77.7 \\
\hline Mexico & 77.0 & 71.3 \\
\hline Average & 77.6 & 64.8 \\
\hline SD & 8.1 & 11.6 \\
\hline
\end{tabular}

NOTE: Based on dendrogram available upon request 
Table 8. Indicators of generosity by cluster, 2013

\begin{tabular}{|c|c|c|c|c|c|c|c|}
\hline Country & $\begin{array}{l}\text { Antiretroviral } \\
\text { therapy } \\
\text { coverage (\% of } \\
\text { people living } \\
\text { with HIV) } \\
\end{array}$ & $\begin{array}{l}\text { Health } \\
\text { expenditure, } \\
\text { public (\% of GDP) }\end{array}$ & $\begin{array}{l}\text { Births attended } \\
\text { by skilled health } \\
\text { staff (\% of total) }\end{array}$ & $\begin{array}{l}\text { Mortality rate, } \\
\text { neonatal (per } \\
1,000 \text { live births) }\end{array}$ & $\begin{array}{l}\text { Risk of } \\
\text { catastrophic } \\
\text { expenditure for } \\
\text { surgical care }(\% \text { of } \\
\text { people at risk) }\end{array}$ & $\begin{array}{l}\text { Health insurance } \\
\text { (\% salaried } \\
\text { workers) }\end{array}$ & $\begin{array}{l}\text { Health insurance } \\
\text { (\% self } \\
\text { employed) }\end{array}$ \\
\hline Chile & 45.00 & 3.63 & 99.83 & 5.20 & 30.20 & 96.00 & 91.40 \\
\hline Colombia & 39.00 & 5.22 & 99.05 & 9.10 & 28.60 & 92.80 & 88.40 \\
\hline Uruguay & 43.00 & 6.07 & 98.20 & 5.50 & 20.30 & 99.10 & 96.10 \\
\hline Costa Rica & 45.00 & 6.91 & 98.40 & 6.40 & 29.20 & 87.80 & 77.70 \\
\hline Mexico & 45.00 & 3.26 & 96.00 & 7.70 & 27.80 & 77.00 & 71.30 \\
\hline Average & 43.40 & 5.02 & 98.30 & 6.78 & 27.22 & 90.54 & 84.98 \\
\hline SD & 2.61 & 1.56 & 1.43 & 1.62 & 3.97 & 8.65 & 10.21 \\
\hline Argentina & 60.00 & 2.74 & 97.04 & 6.80 & 10.70 & 77.80 & 53.00 \\
\hline Peru & 41.00 & 3.05 & 86.70 & 8.90 & 36.10 & 67.90 & 57.20 \\
\hline Average & 50.50 & 2.89 & 91.87 & 7.85 & 23.40 & 72.85 & 55.10 \\
\hline SD & 13.44 & 13.44 & 13.44 & 13.44 & 13.44 & 13.44 & 13.44 \\
\hline & & & & & & & \\
\hline Ecuador & 36.00 & 3.86 & 93.70 & 11.40 & 45.40 & 66.00 & 23.00 \\
\hline Panama & 43.00 & 5.80 & 91.40 & 10.20 & 35.00 & 73.00 & 24.70 \\
\hline El Salvador & 43.00 & 4.63 & 99.50 & 8.90 & 31.20 & 51.00 & 11.70 \\
\hline Average & 40.67 & 4.76 & 94.87 & 10.17 & 37.20 & 63.33 & 19.80 \\
\hline SD & 4.04 & 0.98 & 4.17 & 1.25 & 7.35 & 11.24 & 7.07 \\
\hline & & & & & & & \\
\hline Bolivia & 14.00 & 4.24 & 84.80 & 20.70 & 49.60 & 45.40 & 19.30 \\
\hline Paraguay & 25.00 & 4.78 & 95.80 & 11.80 & 63.20 & 45.60 & 15.50 \\
\hline Honduras & 43.00 & 4.46 & 82.90 & 11.80 & 58.40 & 37.20 & 1.00 \\
\hline Nicaragua & 28.00 & 4.42 & 88.00 & 10.60 & 40.40 & 36.30 & 2.70 \\
\hline Guatemala & 38.00 & 2.32 & 62.80 & 14.30 & 50.10 & 44.50 & 7.60 \\
\hline Average & 29.60 & 4.04 & 82.86 & 13.84 & 52.34 & 41.80 & 9.22 \\
\hline SD & 11.37 & 0.98 & 12.25 & 4.06 & 8.80 & 4.64 & 7.96 \\
\hline
\end{tabular}


Table 9. Indicators of equity by cluster, 2013

\begin{tabular}{|c|c|c|c|c|c|c|}
\hline & $\begin{array}{c}\text { Health } \\
\text { expenditure, } \\
\text { private (\% of } \\
\text { GDP) }\end{array}$ & $\begin{array}{l}\text { Health insurance } \\
\text { (\% salaried } \\
\text { workers) Q1vsQ5 }\end{array}$ & $\begin{array}{l}\text { Health insurance } \\
\text { (\% self employed), } \\
\text { Q1vsQ5 }\end{array}$ & $\begin{array}{l}\text { Health insurance (\% } \\
\text { salaried workers) } \\
\text { Domestic vs Public } \\
\text { sector employees }\end{array}$ & $\begin{array}{l}\text { Health insurance } \\
\text { (\% salaried } \\
\text { workers) }\end{array}$ & $\begin{array}{l}\text { Health insurance } \\
\text { (\% self employed) }\end{array}$ \\
\hline Ecuador & 3.4 & 34.1 & 21.0 & 39.9 & 66.0 & 23.0 \\
\hline Panama & 2.3 & 40.0 & 22.3 & 45.4 & 73.0 & 24.7 \\
\hline Argentina & 2.3 & 45.1 & 29.9 & 45.0 & 77.8 & 53.0 \\
\hline Bolivia & 1.7 & 37.0 & 53.7 & 19.3 & 45.4 & 19.3 \\
\hline Average & 2.4 & 39.0 & 31.7 & 37.4 & 65.6 & 30.0 \\
\hline SD & 0.7 & 4.7 & 15.1 & 12.3 & 14.3 & 15.5 \\
\hline Honduras & 4.7 & 1.5 & 4.9 & 3.1 & 37.2 & 1.0 \\
\hline Nicaragua & 4.0 & 16.4 & 5.7 & 2.3 & 36.3 & 2.7 \\
\hline El Salvador & 2.3 & 12.1 & 3.2 & 10.4 & 51.0 & 11.7 \\
\hline Guatemala & 4.0 & 13.2 & 13.6 & 8.3 & 44.5 & 7.6 \\
\hline Paraguay & 5.7 & 14.0 & 9.1 & 18.0 & 45.6 & 15.5 \\
\hline Average & 4.1 & 11.4 & 7.3 & 8.4 & 42.9 & 7.7 \\
\hline SD & 1.2 & 5.8 & 4.1 & 6.4 & 6.2 & 6.1 \\
\hline Mexico & 3.0 & 88.7 & 125.1 & 73.1 & 77.0 & 71.3 \\
\hline Peru & 2.2 & 83.6 & 149.8 & 53.4 & 67.9 & 57.2 \\
\hline Average & 2.6 & 86.1 & 137.5 & 63.3 & 72.5 & 64.3 \\
\hline SD & 0.6 & 3.6 & 17.5 & 13.9 & 6.4 & 10.0 \\
\hline Chile & 3.9 & 99.9 & 107.3 & 96.2 & 96.0 & 91.4 \\
\hline Uruguay & 2.6 & 98.0 & 96.2 & 99.1 & 99.1 & 96.1 \\
\hline Colombia & 1.6 & 91.1 & 98.5 & 89.7 & 92.8 & 88.4 \\
\hline Costa Rica & 2.6 & 71.8 & 80.1 & 75.5 & 87.8 & 77.7 \\
\hline Average & 2.7 & 90.2 & 95.5 & 90.1 & 93.9 & 88.4 \\
\hline SD & 0.9 & 12.8 & 11.3 & 10.5 & 4.8 & 7.8 \\
\hline
\end{tabular}

NOTE: based on dendrogram available upon request 
Figure 4. Health care, segmentation in equity: private health spending (\% total spending), 2000 and 2013

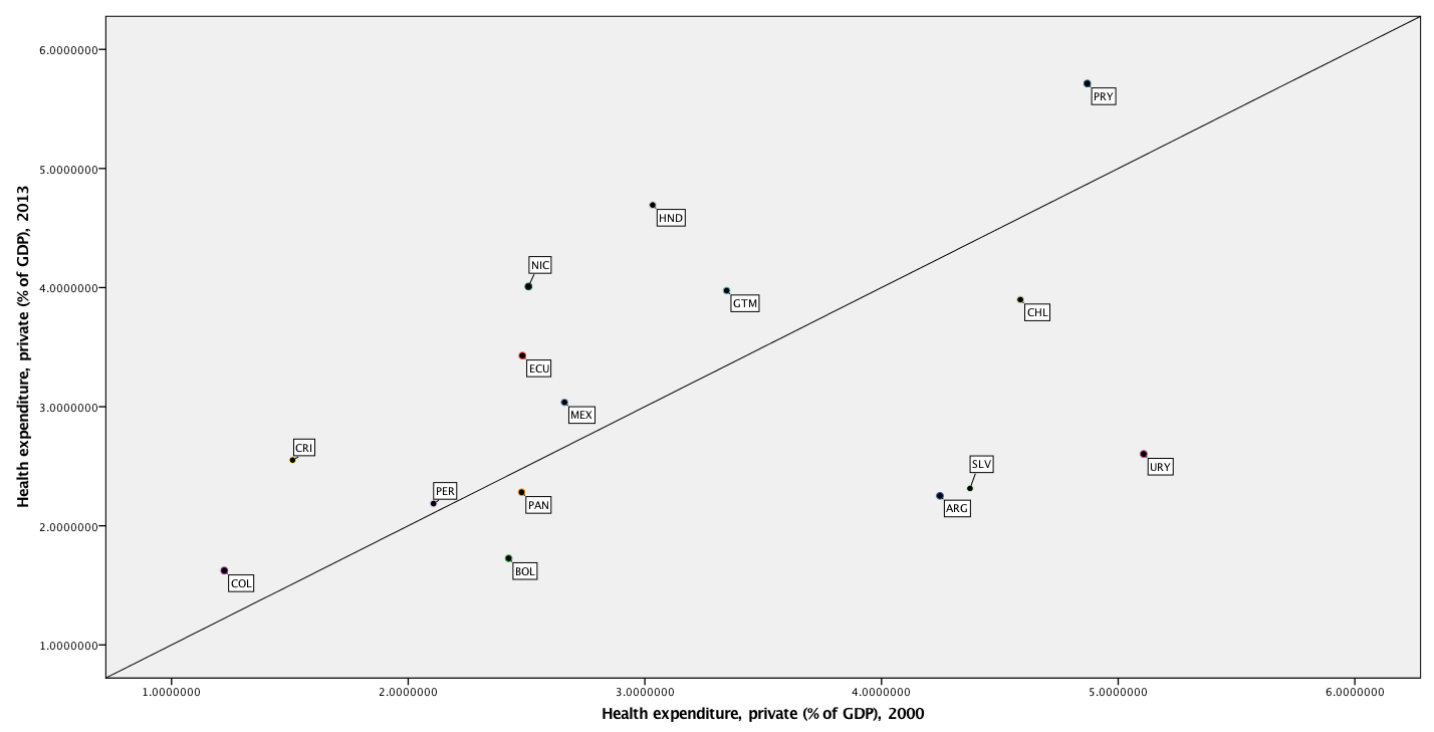


Table 10. Segmentation per dimension: countries' relative position, 2013

\begin{tabular}{|l|l|l|l|}
\hline Country & Coverage & Generosity & Equity \\
\hline Uruguay & & & \\
\hline Chile & & & \\
\hline Colombia & & & \\
\hline Costa Rica & & & \\
\hline Mexico & & & \\
\hline Peru & & & \\
\hline Argentina & & & \\
\hline Panama & & & \\
\hline Ecuador & & & \\
\hline El Salvador & & & \\
\hline Bolivia & & & \\
\hline Guatemala & & & \\
\hline Honduras & & & \\
\hline Nicaragua & & & \\
\hline Paraguay & & & \\
\hline Coding & & & \\
\hline
\end{tabular}

